\title{
ニュートリゲノミクスによる食品の機能性解析
}

\author{
高橋陽子 \\ 独立行政法人 農業・食品産業技術総合研究機構 食品総合研究所 \\ 食品機能研究領域 栄養機能ユニット \\ 干305-8642 茨城県つくば市観音台 2-1-12 \\ 電話:029-838-8083, FAX:029-838-7996, E-mai1:youkot@affrc. go. jp \\ キーワード : DNA マイクロアレイ、機能性食品、食品成分、脂質代謝、大豆食品
}

\section{Nutrigenomic analysis of food functionality}

\author{
Yoko Takahashi \\ Food Research Institute, National Agriculture and Food Research Organization \\ 2-1-12 Kannnondai, Tsukuba, Ibaraki 305-8642, Japan
}

\section{Summary}

Nutrigenomics is a coined word created from nutrition and genomics. This new research area has been developed to investigate how nutritional components affect all metabolic pathways and homeostasis in organisms, and which genomic types are susceptible to specific nutrients. DNA microarray is a typical nutrigenomics tool for analyzing comprehensive metabolic condition of organism in the level of gene expression. We can obtain huge amount of information suggesting wide functionality of food components from microarray analysis. However, appropriate statistic analyses are required to understand the true meaning of the data. The versatility of DNA microarray analysis may be applicable to measurement of functionality of whole foods as well as food components, although it is difficult to speculate the functionality of the food from the functionalities of the individual food components. Here, we tried to 
elucidate the functionality of dietary freeze-dried tofu by comparing the functionality of soy protein and isoflavone in rats by DNA microarray analysis. The findings from the experiment suggested that the protein, and not isoflavone, fraction of freeze-dried tofu reduced lipogenesis in liver through gene expression, and that this may result in lower serum lipid levels.

Key words : DNA microarray, functional foods, food components, lipid metabolism, soy foods

\section{1. はじめに}

食品成分の機能性研究はここ数十年の間に飛躍的な発展を遂げ、その成果はマスメディア等 と通じて広く知られるようになっている。また、「機能性食品」「特定保健用食品（トクホ）」 等と呼ばれる健康の維持・増進が期待される食品の開発や、日常の食生活の基本となる食育活 動にも活かされている。一方、食品成分の機能性に関する情報の汇濫、機能性を謳った食品が 無秩序に摂取されるリスク、成分の機能性は学術的に認められていても科学的根拠は限定的、 といった問題が表面化しており、従来の研究だけでは解明できない課題が山積する。未解明の 機能性や潜在リスクを明らかにする一つの方法として、「ニュートリゲノミクス」の導入が挙 げられる。ニュートリゲノミクスとは、nutrition（栄養）とgenomics（遺伝情報）を組み合 わせて作られた造語である。本稿では、ニュートリゲノミクスとは何か、ニュートリゲノミク ス研究で何が解明されるかについて、我々の研究例を紹介しながら解説したい。また、「食品 成分」と「食品そのもの」の機能性の違いについても触れたい。

\section{2. ニュートリゲノミクスとは}

ニュートリゲノミクスは、ポストゲノム時代の研究の一つして、栄養はどのようにヒトの 代謝経路やホメオスターシスに影響するのか、また、栄養による代謝調節は食餌と関係の深い 疾病の初期段階にどのように影響するのか、さらに、どのような遺伝子発現型を持つ個人がこ のような疾患にかかりやすいのかを総合的に解明するために発達したものである11。ニュート リゲノミクスでは、食品 (成分) を摂取した時に起こる生体内の代謝変動を、遺伝子発現 (mRNA) レベルで解析するトランスクリプトーム研究が最も一般的であるが、近年のバイオテクノロジ 一技術の進展により、蛋白質レベル(プロテオーム)、代謝物レベル(メタボローム)の解析一展 開されている。遺伝子発現レベルの解析では、DNA マイクロアレイと呼ばれるツールを使って、 
一度の解析で数万もの遺伝子の発現量を測定する。これにより、どの食品成分が生体の代謝調 節作用にどのように影響しているのかを網羅的に知ることができる。

ニュートリゲノミクスでは一度の解析で大量のデータを得られるため、従来の知見以上に食 品成分の作用メカニズムを詳細に解析できるほか、これまで研究されていなかった新規の機能 性を探索したり、機能性に加えて食品成分の安全性を予測したりすることも可能になる。また、 個人の体質差を遺伝子の多様性（SNP, Single Nucleotide Polymorphism：一塩基多型）から 読み取ることで、摂取する食品（成分）に対する感受性を予測し、各個人に最適な食品の摂取 方法や摂取量を検討寸る「栄養のテーラーメイド化」にも応用できると期待されている。しか しながら、DNA マイクロアレイで得られるような大量のデータを扱う際には、統計学的に正し い解釈がなされるよう注意が必要である。

\section{3. 食品成分と食品の違い}

ヒトはサプリメントのような単一の食品成分ではなく、食品や調理された食慨を摂取して生 命活動を営んでいる。したがって、食品や食餌の作用性こそが真の機能性であり、本来の食生 活に沿うものと言える。しかし実際の食品の機能性研究では、まず作用因子となる成分を特定 し、その単一成分の機能性を解析するのが一般的である。食品成分と食品の違いは、単一化合 物か、多数の栄養素や微量成分の集合体か、にある。食品の作用は、それに含まれる個々の成 分の機能性を単純に合算したものと同一とは限らない。食品中の各成分同士が相乗的あるいは 相殺的な作用を示寸可能性があるからである。また、農畜産物や水産物を加工した食品では、 加工の過程に伴う成分の物理的・化学的変化や、加工に必要な成分の添加および加工による成 分の損失等が起きるため、機能性はさらに複雑になると考えられる。

\section{4. ニュートリゲノミクスを用いた研究例 ${ }^{3)}$}

大豆は水溶性食物繊維、ポリフェノール類、不飽和脂肪酸等の機能性成分を含み、心藏病や 高コレステロール血症の予防や改善に有効な食品として知られている ${ }^{2)}$ 。なかでも大豆タンパ ク質とイソフラボンは、その血清脂質低下作用について動物やヒトを対象とした研究が数多く 実施されてきた。では、単体の大豆成分ではなく、大豆や大豆食品の機能性はどうだろうか。 また、大豆中の個々の成分はそれぞれどのような役割を果たすのだろうか。我々は大豆食品で 
ある凍り豆腐 (高野豆腐) の機能性について、大豆タンパク質とイソフラボンの作用と比較し て検討した ${ }^{3)}$ 。

A

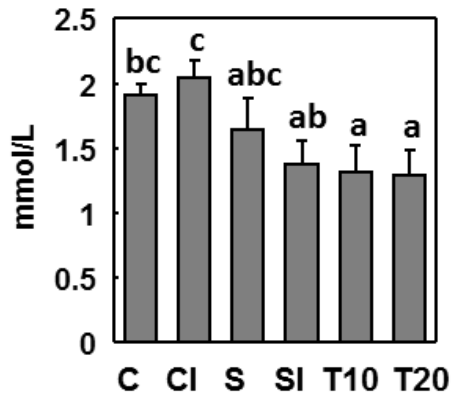

B

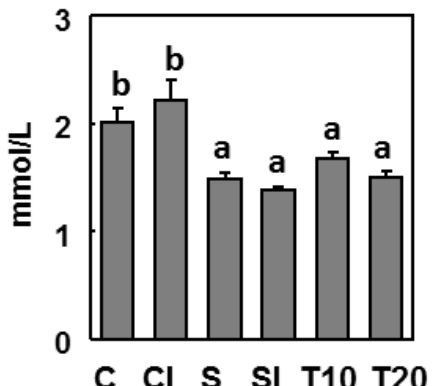

\section{C: Casein}

$\mathrm{Cl}$ : Casein + Isoflavone

S: Soy protein

SI: Soy protein + Isoflavone

T10: Freeze-dried tofu

+ soy protein $(10 \%$ each $)$

T20: Freeze-dried tofu (20\%)

Fig.1. Serum lipid levels in rats. At the end of the 14 day experimental period, rats were weighed and serum lipid and isoflavone levels were measured: $(A)$ triacylglycerol and (B) cholesterol. Values are the mean $\pm S D, n=7-8$. Means without a common letter differ, $p<0.05$.

凍り豆腐中のタンパク質成分の作用を明らかにするため、カゼイン $20 \%$ 食 (C) 、分離大豆 タンパク質 (イソフラボンはほとんど含まない) $20 \%$ 食 (S) 、カゼイン $10 \%$ +凍り豆腐（タ ンパク質量換算で $10 \%$ 相当）食（T10）、凍り豆腐（タンパク質量換算で $20 \%$ 相当）食（T20） を調製した。また、凍り豆腐中のイソフラボンの作用を明らかにするため、T20に含まれるイ ソフラボンと等量の大豆イソフラボン $(0.012 \%)$ を、CおよびS に添加した食慨を調製した （それぞれCI、SI）。以上 6 種類の食䬣により、雄性 SD ラットを 2 週間飼育した。その結果、 血清中の中性脂肪やコレステロールの濃度は、タンパク質源がカゼインの群（C、CI）と比べ て、大豆タンパク質（S、SI）や涷り豆腐（T10、T20）群で低下した（Fig. 1）。しかしイソ フラボン添加は、血清脂質濃度の有意な低下をもたらさなかった。このことから、凍り豆腐は 血清脂質低下作用を有する食品であることが明らかとなり、その作用は主に大豆タンパク質に よるものと考えられた。

次に、凍り豆腐の脂質濃度低下作用のメカニズムを明らかにするため、生体のあらゆる代謝 作用の中心となる肝蔵で、遺伝子発現レベルの変化をDNA マイクロアレイで調ベた。各群 5 匹 の肝臓サンプルより得られた全ての遺伝子発現量データから、主成分分析により食既群間の相 違性およびその相違性を決定する因子を推定した。主成分分析とは、データに含まれる変数間 の関係や特徵を把握しやすいように、複数の変数間の共分散を少数の合成変数で説明する手法 
である。分析の結果、上位 2 つ主成分で $80 \%$ 以上の情報を説明でき、第 1 主成分は S・SI 群と C・CI 群を分離し、第 2 主成分は $\mathrm{T} 10$ ・T20 群とその他の群を分離するものであることが

\section{PCA Score}

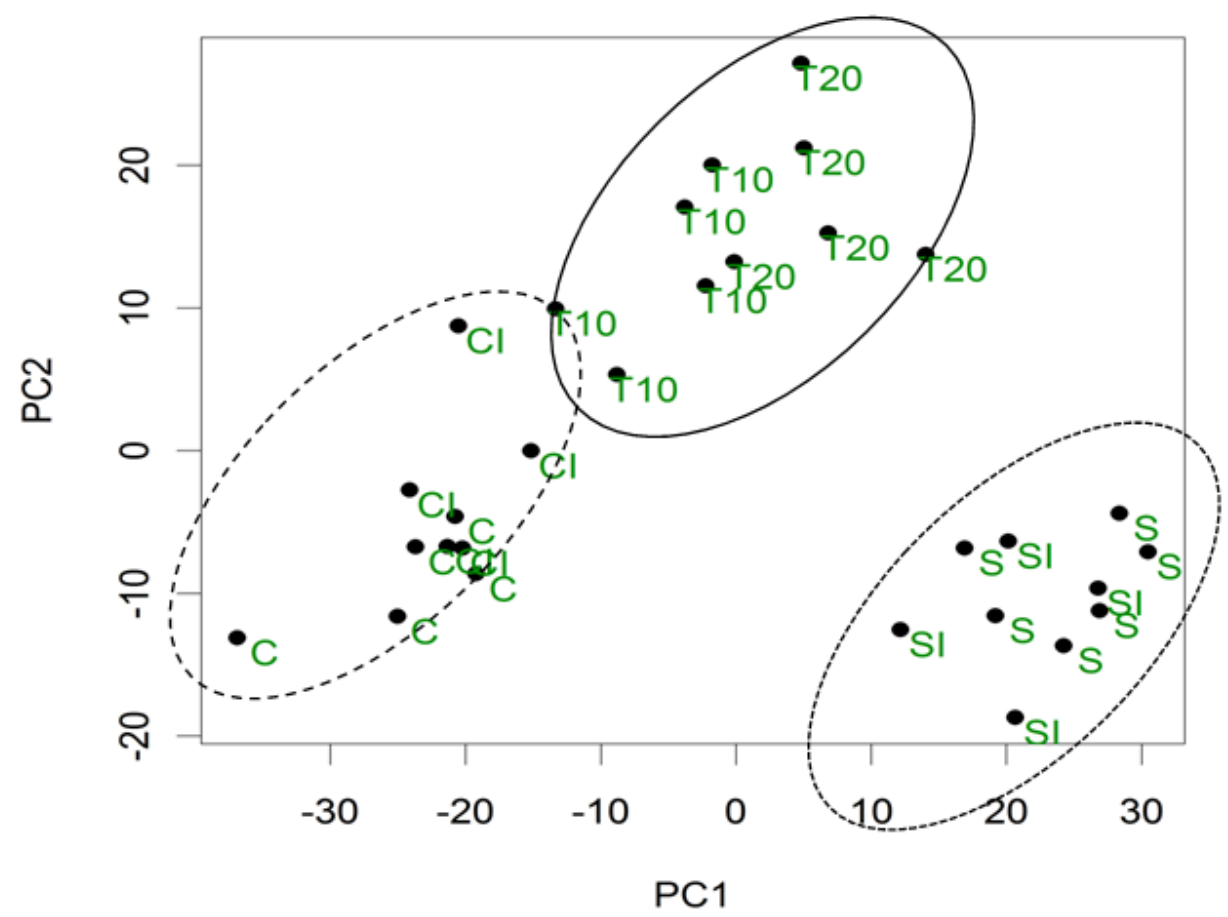

Fig. 2. Principal component analysis applied to individual samples. Score plots of PC1 compared with PC2 were derived from hepatic gene expression in rats fed $\mathrm{C}, \mathrm{Cl}, \mathrm{S}, \mathrm{SI}, \mathrm{T} 10$, or T20. Each dot represents a rat sample, $n=5$.

示された (Fig. 2)。上位2つの主成分を軸とした図に各個体を表すデータをプロットすると、 同じタンパク質源が含まれる食慨を摂取した個体同士が集まり、大きく 3 群に分離された (Fig. 2 中の円で示す）。このことは、肝蔵での遺伝子発現は食餌タンパク質源の違いによる影響を 大きく受けたが、イソフラボンはほとんど影響しなかったことを示唆している。

また、どのような代謝系が食餌の影響を受けたのかを、肝蔵で発現する全遺伝子の発現量デ ータから、各遺伝子が有する生物学的機能を遺伝子データベース NetAffyx ${ }^{5}$ およびRat Genome Database（RGD） $)^{4)}$ で検索した。群間の発現量差が有意であった遺伝子が多く含まれていた上位 20 の生物学的機能のうち、脂質代謝に関連する機能・代謝パスウェイが半数を占めていた 
（Table 1）。したがって、凍り豆腐や大豆成分が含まれる食餌は、肝蔵で発現する全ての代 謝機能の中でも脂質代謝系に強い影響を与えると言える。さらに、この検索で選抜された脂質 代謝関連遺伝子を各群間の発現変化パターンで分類すると、発現量がカゼイン群（C、CI）で 増加、大豆タンパク質（S、SI）および涷り豆腐（T10、T20）群で減少した遺伝子が多く出現 した。この変化パターンを持った遺伝子の多くは脂質合成関連遺伝子であった。リアルタイム PCR によりこれらの遺伝子の発現量を確認すると、DNA マイクロアレイのデータとほぼ一致し た（Table 2）。また、主成分分析の結果と同様に、イソフラボンは脂質代謝関連遺伝子の発 現にもほとんど影響していなかった。以上の結果から、凍り豆腐食は大豆タンパク質と同様に 肝臓での脂質合成を抑制する作用を持つこと、そしてこの作用が血清の脂質濃度低下作用に寄 与することが示唆された。

\begin{tabular}{rrrlrrr}
\hline Rank & GO ID & Category of GO Biological Process & $\begin{array}{c}\text { Frequency } \\
\text { selected }\end{array}$ & $\begin{array}{c}\text { Total } \\
\text { content }\end{array}$ & $P$-values \\
\hline 1 & 8152 & metabolic process & 90 & 819 & 0 \\
2 & 55114 & oxidation reduction & 65 & 427 & 0 \\
3 & 6629 & lipid metabolic process & 35 & 205 & $7.86 \mathrm{E}-12$ \\
4 & 8610 & lipid biosynthetic process & 23 & 90 & $1.53 \mathrm{E}-11$ \\
5 & 42493 & response to drug & 35 & 289 & $4.78 \mathrm{E}-08$ \\
6 & 1676 & long-chain fatty acid metabolic process & 8 & 13 & $1.13 \mathrm{E}-07$ \\
7 & 6631 & fatty acid metabolic process & 17 & 87 & $2.87 \mathrm{E}-07$ \\
8 & 6694 & steroid biosynthetic process & 14 & 63 & $7.17 \mathrm{E}-07$ \\
9 & 6633 & fatty acid biosynthetic process & 12 & 48 & $1.33 \mathrm{E}-06$ \\
10 & 7067 & mitosis & 16 & 89 & $1.83 \mathrm{E}-06$ \\
11 & 38 & very-long-chain fatty acid metabolic process & 6 & 9 & $2.79 \mathrm{E}-06$ \\
12 & 6879 & cellular iron ion homeostasis & 10 & 35 & $3.16 \mathrm{E}-06$ \\
13 & 6695 & cholesterol biosynthetic process & 9 & 28 & $3.84 \mathrm{E}-06$ \\
14 & 6637 & acyl-CoA metabolic process & 7 & 18 & $1.37 \mathrm{E}-05$ \\
15 & 8202 & steroid metabolic process & 13 & 72 & $1.58 \mathrm{E}-05$ \\
16 & 51301 & cell division & 17 & 119 & $1.72 \mathrm{E}-05$ \\
17 & 10033 & response to organic substance & 17 & 123 & $2.60 \mathrm{E}-05$ \\
18 & 14070 & response to organic cyclic substance & 18 & 138 & $3.21 \mathrm{E}-05$ \\
19 & 7584 & response to nutrient & 18 & 142 & $4.60 \mathrm{E}-05$ \\
20 & 7049 & cell cycle & 26 & 267 & $9.17 \mathrm{E}-05$ \\
\hline
\end{tabular}

The categories with more than six genes were selected. The top 20 categories with $P$-values less than 0.01 are shown. $n=5$.

Table 1. Over-represented Gene Ontology involving hepatic genes expressed differently between the $\mathrm{C}$-fed and other groups. 


\begin{tabular}{lcccccc}
\hline Relative mRNA expression (\%) & $\mathrm{C}$ & $\mathrm{Cl}$ & $\mathrm{S}$ & $\mathrm{SI}$ & $\mathrm{T} 10$ & T20 \\
\hline Acetyl-CoA carboxylase & $100 \pm 33^{\mathrm{ab}}$ & $107 \pm 29^{\mathrm{a}}$ & $75.8 \pm 22.3^{\mathrm{bc}}$ & $71.0 \pm 34.2^{\mathrm{c}}$ & $63.4 \pm 11.1^{\mathrm{c}}$ & $53.9 \pm 13.6^{\mathrm{c}}$ \\
Fatty acid synthase & $100 \pm 25^{\mathrm{a}}$ & $97.7 \pm 29.7^{\mathrm{a}}$ & $50.4 \pm 23.2^{\mathrm{b}}$ & $55.7 \pm 36.5^{\mathrm{b}}$ & $40.0 \pm 7.5^{\mathrm{b}}$ & $32.4 \pm 5.7^{\mathrm{b}}$ \\
ATP-citrate lyase & $100 \pm 8^{\mathrm{a}}$ & $108 \pm 8^{\mathrm{a}}$ & $72.9 \pm 9.0^{\mathrm{b}}$ & $71.5 \pm 11.7^{\mathrm{bc}}$ & $63.4 \pm 5.1^{\mathrm{bc}}$ & $49.5 \pm 4.8^{\mathrm{c}}$ \\
Glucose 6-phosphate dehydrogenas & $100 \pm 17^{\mathrm{a}}$ & $99.6 \pm 28.6^{\mathrm{a}}$ & $71.4 \pm 10.7^{\mathrm{b}}$ & $74.4 \pm 11.1^{\mathrm{b}}$ & $62.4 \pm 8.8^{\mathrm{b}}$ & $58.7 \pm 7.0^{\mathrm{b}}$ \\
Malic enzyme & $100 \pm 26^{\mathrm{a}}$ & $90.7 \pm 24.1^{\mathrm{a}}$ & $45.7 \pm 7.3^{\mathrm{bc}}$ & $37.3 \pm 4.6^{\mathrm{c}}$ & $55.3 \pm 8.4^{\mathrm{b}}$ & $35.0 \pm 6.1^{\mathrm{c}}$ \\
HMG-CoA reductase & $100 \pm 42.7^{\mathrm{a}}$ & $89.0 \pm 31.8^{\mathrm{ab}}$ & $60.2 \pm 17.6^{\mathrm{c}}$ & $54.4 \pm 13.2^{\mathrm{c}}$ & $65.9 \pm 16.3^{\mathrm{bc}}$ & $57.9 \pm 11.6^{\mathrm{c}}$ \\
\hline Values are mean $\pm \mathrm{SD}, n=7-8$. Means in a row with superscripts without a common letter differ, $p<0.05$. & & &
\end{tabular}

Table 2. Effect of dietary protein source and isoflavone supplementation on the gene expression involved in hepatic lipid metabolism in rats fed C, Cl, S, SI, T10, or T20.

\section{5. おわりに}

食品の機能性は、その食品に多く含まれる単一成分で見出された、限定的な作用によって説 明されてきている。しかし、食品は多くの成分から構成されているため、必ずしもその中の一 成分の機能性だけで食品トータルの機能を説明できないと考えられる。食品の作用は単一成分 の作用よりも複雑であり、従来の機能性研究の手法では科学的エビデンスの取得には限界があ る。これまで解説してきたように、日常生活に沿った「食品」の機能性を評価するためには二 ユートリゲノミクス研究が不可欠になると考えられる。

\section{謝辞}

本研究の遂行にあたり、DNA マイクロアレイ解析に御協力下さいました、秋田県立大学生物 資源科学部の小西智一准教授に厚く御礼申し上げます。本研究の一部は、農林水産省委託プロ ジェクト「食品・農産物の信頼性確保と機能性解析のための基盤技術の開発」によって実施さ れました。

\section{参考文献}

1. Müller M and Kersten S. Nature Reviews, 4: 315-322, 2003.

2. Sacks FM, Lichtenstein A, Van Horn L, Harris W, Kris-Etherton P, Winston M. Circulation, 113: 1034-1044, 2006.

3. Takahashi Y and Konishi T. J Agric Food Chem, 59: 8976-8984, 2011.

4. http://rgd.mcw.edu/

5. http://www.affymetrix.com/analysis/index.affx 